\title{
PENGARUH GAYA KEPEMIMPINAN DAN KOMPENSASI TERHADAP PRESTASI KERJA KARYAWAN (Studi pada PT JAPFA COMFEED INDONESIA (JCI) Tbk Devisi Fam 1 Padang)
}

\author{
Andi Yolanda Oktavia Lubis, Febs ri Susanti \\ Sekolah Tinggi Ilmu Eknomi "KBP" \\ febsrisusanti@akbpstie.ac.id
}

ABSTRACT

\begin{abstract}
Organization is a social unity that is coordinated sadardengan with a reactive boundary in the identified, work continuously to achieve the goal. In various fields, especially life beroganisasi, human factor is the main problem in every activity that is inside. All actions taken in every activity are initiated and determined by the human being who is a member of a Company. The company requires the existence of potential human resources factors both leaders and employees, the pattern of duties and supervision that is the determinant of achieving corporate goals. Human resources are central figures in organizations and companies. In order for management activities to run well, the Company must have knowledgeable employees and high skills and efforts to manage the company optimally so that employee work increases. Based on research results obtained after testing of 100 respondents who are employees who work in PT. Japfa Comfeed Indonesia Padang it can be concluded that the Style of Leadership and Compensation together have a significant effect on Job Performance in PT. Japfa Comfeed Indonesia because it has $F$-> count of $F$ - table and significance value $<0.05$. The results of this study are in line with the Caesar (2015) study which found the result that simultaneously the leadership style and compensation variables have a positive and significant effect on employee performance in PT Mustika Ratu East Jakarta. The results of this study indicate that employees have a good job performance due to leadership style and compensation given the leadership of the company well.
\end{abstract}

Keyword: leadership style, compensation, employee performance

\section{PENDAHULUAN}

Pada berbagai bidang khususnya kehidupan beroganisasi, faktor manusia merupakan masalah utama disetiap kegiatan yang ada didalamnya. Perusahaan harus memiliki karyawan yang berpengetahuan dan keterampilan tinggi serta usaha untuk mengelola perusahaan secara optimal sehingga kerja karyawan meningkat. Peranan seorang pemimpin dalam organisasi sangat penting, akan tetapi walaupun begitu seorang memimpin tidak boleh mengabaikan pentingnya peran karyawan. Karyawan atau bawahan adalah salah satu pelaksana berbagai macam kegiatan atau tugas yang sangat membutuhkan motivasi guna meningkatkan semangat kerja karyawan, yang apa akhirnya akan mampu meningkatkan prestasi kerja karyawan tersebut.

Kepemimpinan yang efektif sangat Martinis Yamin dan Maisah (2010: 74) menyatakan kepemimpinan adalah suatu proses mempengaruhi yang dilakukan oleh seseorang dalam mengelola anggota kelompoknya untuk mencapai tujuan organisasi. Seorang pimpinan yang efektif tidak hanya bisa mempengaruhi bahannya, tapi bisa juga menjamin bahwa para karyawannya tersebut dapat bekerja dengan seluruh kemampuan yang mereka miliki. Hal ini dapat dperjelaskan bahwa kepemimpinan merupakan kemampuan orang yang mempunyai jabatan yang berhak memberikan pengaruh, pendapatan, pengarahan, dan meminta orang lain terutama bawahannya agar mereka bekerja dengan semangat dan keyakinan yang tinggi untuk mencapai tujuan organisasi.

Untuk mencapai tujuan organisasi yang telah ditargetkan diperlukan adanya prestasi kerja dan gaya kepemimpinan. Prestasi kerja karyawan berarti prestasi atau kontribusi yang diberikan oleh karyawan dalam melaksanakan tugas dan tanggung jawab 
serta fungsinya sebagai karyawan di perusahaan. Selain itu, prestasi kerja dibatasi sebagai hasil dari perilaku kerja karyawan yang menunjang tercapainya output atau prestasi dan berkaitan dengan usaha untuk menyelesaikan tugasnya pada periode waktu tertentu. Hasil yang tercermin pada perilaku tersebut dipengaruhi antara lain oleh motivasi. (Mangkunegara, 2005:91).

Menurut Hasibuan (2000:143), bahwa aspek-aspek yang dinilai dari prestasi kerja mencakup sebagai berikut:

1. Kesetiaan

Kesetiaan ini dicerminkan oleh kesediaan karyawan menjaga dan membela organisasi di dalam maupun di luar pekerjaan dari rongrongan orang yang tidak bertanggung jawab.

2. Prestasi kerja

Penilai menilai hasil kerja baik kualitas maupun kuantitas yang dapat dihasilkan karyawan tersebut dari uraian pekerjaan.

3. Kejujuran

Penilai menilai kejujuran dalam melaksanakan tugastugasnya memenuhi perjanjian baik bagi dirinya sendiri maupun terhadap orang lain seperti kepada para bawahannya.

4. Kedisiplinan

Penilai menilai disiplin karyawan dalam mematuhi peraturan-peraturan yang ada dan melakukan pekerjaannya sesuai dengan instruksi yang diberikan kepadanya.

5. Kreativitas

Penilai menilai kemampuan karyawan dalam mengembangkan kreativitasnya menyelesaikan pekerjaannya, sehingga bekerja lebih berdaya guna dan berhasil guna.

6. Kerja sama

Penilai menilai kesediaan karyawan berpartisipasi dan bekerja sama dengan karyawan lainnya secara vertikal dan horizontal di dalam maupun di luar pekerjaan sehingga hasil pekerjaan akan semakin baik.

7. Kepemimpinan

Penilai menilai kemampuan untuk memimpin, berpengaruh, mempunyai pribadi yang kuat, dihormati, berwibawa, dan dapat memotivasi orang lain atau bawahannya untuk bekerja secara efektif.

8. Kepribadian

Penilai menilai karyawan dari sikap perilaku, kesopanan, periang, disukai, memberi kesan menyenangkan, memperlihatkan sikap yang baik, serta berpenampilan simpatik dan wajar.

9. Prakarsa

Penilai menilai kemampuan berpikir yang orisinal berdasarkan inisiatif sendiri untuk menganalisis, menilai, menciptakan, memberikan alasan, mendapatkan kesimpulan, dan membuat keputusan penyelesaian masalah yang dihadapinya.

10. Kecakapan

Penilai menilai kecakapan karyawan dalam menyatukan dan menyelaraskan bermacam-macam elemen yang semuanya terlibat di dalam penyusunan kebijaksanaan dn di dalam situasi manajemen.

11. Tanggung jawab

Penilai menilai kesediaan karyawan dalam mempertanggung jawabkan kebijaksanaannya, pekerjaan, dan hasil kerjanya, sarana dan prasarana yang dipergunakannya, serta perilaku kerjanya.

Gaya Kepemimpinan merupakan norma perilaku yang digunakan oleh seseorang pada saat orang tersebut mencoba mempengaruhi perilaku orang lain. Seorang pemimpin harus menerapkan gaya kepemimpinan untuk mengelola 
karyawannya, karena seorang pemimpin akan sangat mempengaruhi keberhasilan organisasi dalam mencapai tujuannya. Perusahaanmenggunakanpenghargaan atau hadiah dan ketertiban sebagai alat untuk memotivasi karyawan. Pemimpin mendengar ide-ide dari para bawahan sebelum mengambil keputusan. Robinss (2006) mengidentifikasi empat jenis gaya kepemimpinan antara lain:

1. Gaya kepemimpinan kharismatik

Para pengikut terpacu
kemampuan kepemimpinan yang
heroik atau yang luar biasa ketika
mereka mengamati perilaku-perilaku
tertentu pemimpin mereka.Terdapat
lima karakteristik pokok pemimpin
kharismatik:

a. Visi dan artikulasi.

Dia memiliki visi ditujukan dengan sasaran ideal yangberharap masa depan lebih baik daripada status quo, dan mampumengklarifikasi

pentingnya visi yang dapat dipahami orang lain.

b. Rasio personal.

Pemimpin kharismatik
bersedia menempuh risiko
personal tinggi, menanggung
biaya besar, dan terlibat kedalam
pengorbanan diri untuk meraih
visi.

c. Peka terhadap lingkungan.

Mereka mampu menilai secara realistis kendala lingkungan dan sumber daya yang dibutuhkan untuk membuat perubahan.

d. Kepekaan terhadap kebutuhan pengikut.

Pemimpin
perseptif (sangat pengertian)
terhadap kemampuan orang lain
dan responsif terhadap kebutuhan
dan perasaan mereka.

e. Perilaku tidak konvensional.

$\begin{array}{ll} & \text { Pemimpin kharismatik } \\ \text { terlibat dalamperilaku yang }\end{array}$

dianggap baru dan berlawanan dengan norma.

2. Gaya kepemimpinan transaksional Pemimpin transaksional merupakan pemimpin yang memandu ataumemotivasi para pengikut mereka menuju sasaran yang ditetapkan dengan mempe lebih berfokus pada hubungan pemimpinbawahan tanpa adanya usaha untuk menciptakan perubahan bagi bawahannya. Terdapat empat karakteristik pemimpin transaksional:

a. Imbalan kontingen:

Kontrak pertukaran imbalan atas upaya yangdilakukan, menjanjikan imbalan atas kinerja baik, mengakui pencapaian.

b. Manajemen berdasar pengecualian (aktif):

Melihat dean mencari penyimpangan dari aturan dan standar, menempuh tindakan perbaikan.

c. Manajemen berdasar pengecualian (pasif):

Mengintervensi hanya jika standar tidak dipenuhi.

d. Laissez-Faire:

melepas tanggung jawab, menghindari pembuatan keputusan.

3. Gaya

kepemimpinan

transformasional

Pemimpin transformasional mencurahkan perhatian pada hal-hal dankebutuhan pengembangan dari masing-masing pengikut, Pemimpin transformasional mengubah kesadaran para pengikut akan persoalan-persoalan dengan membantu mereka memandang masalah lama dengan cara-cara baru, dan mereka mampu menggairahkan, membangkitkan, dan mengilhami para pengikut untuk mengeluarkan upaya ekstra demi mencapai sasaran kelompok. 
Terdapat empat karakteristik pemimpin transformasional:

a. Kharisma:

Memberikan visi dan rasa atas misi, menanamkan kebanggaan,meraih penghormatan dan kepercayaan.

b. Inspirasi:

\section{Mengkomunikasikan}

harapan tinggi, menggunakan symboluntuk memfokuskan pada usaha, menggambarkan maksud penting secarasederhana.

c. Stimulasi intelektual:

Mendorong intelegensia, rasionalitas, danpemecahan masalah secara hati-hati.

d. Pertimbangan individual:

Memberikan perhatian pribadi, melayanikaryawan secara pribadi, melatih dan menasehati.

4. Gaya kepemimpinan visioner

Kemamuan menciptakan dan mengartikulasikan visi yang realistis, kredibel,dan menarik mengenai masa depan organisasi atau unit organisasi yang tengahtumbuh dan membaik dibanding saat ini. Visi ini jika diseleksi dandiimplementasikan secara tepat, mempunyai kekuatan besar sehingga bisamengakibatkan terjadinya lompatan awal ke masa depan denganmembangkitkan keterampilan, bakat, dan sumber daya untuk mewujudkannya.

Bukan hanya sekedar gaya kemimpinan dan prestasi kerja karyawan yang memiliki fungsi penting untuk mencapai tujuan perusahaan, di perlukan juga kompensasi untuk memotivasi kerja karyawan. Kompensasi adalah dorongan, upaya dan keinginan yang ada di dalam diri manusia yang mengaktifkan, memberi daya serta mengarahkan perilaku untuk melaksanakan tugas-tugas dengan baik dalam lingkup pekerjaannya (Hakim2006).
Berikut bentuk - bentuk Kompensasi Upah/gaji.

Upah (wages) biasanya berhubungan dengan tarif gaji perjam (semakin lama kerjanya, semakin besar bayarannya). Upah merupakan basis bayaran yang kerap digunakan bagi pekerjapekerja produksi dan pemeliharaan.Sedangkan gaji (salary) umumnya berlaku untuk tarif mingguan, bulanan atau tahunan.

1. Insentif, (incentive) merupakan tambahantambahan gaji diatas atau diluar gaji atau upah yang diberikan oleh organisasi. Program-program insentif disesuaikan dengan memberikan bayaran tambahan berdasarkan produktivitas, penjualan, keuntungankeuntungan atau upaya-upaya pemangkasan biaya.

2. Tunjangan (Benefit)

Contoh-contoh tunjangan seperti asuransi kesehatan, asuransi jiwa, liburan-liburan yang ditanggung perusahaan, program pensiun dan tunjangantunjangan lainnya yang berhubungan dengan kepegawaian.

3. Fasilitas (Facility)

Adalah kenikmatan/fasilitas seperti mobil perusahaan, keanggotaan klub, tempat parkir khusus.

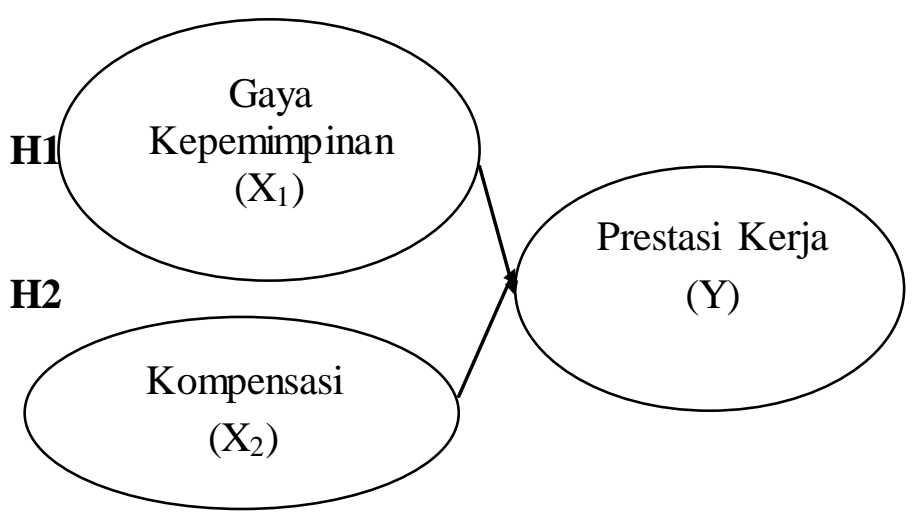

Gambar 2.1 
Kerangka Konseptual

Berdasarkan pada hasil penelitian terdahulu (Yulievianti 2015 dan Diandra, 2015),mengembangankan hipotesis dalam penelitian ini adalah :

$H_{1} \quad$ : Didugagayakepemimpinan berpengaruh positif dan signifikan terhadap prestasi kerja karyawan PT. JAPFA COMFEED INDONESIA Tbk, Devisi FARM 1 PADANG.

$\mathrm{H}_{2} \quad$ : Diduga kompensasi sangat berpengaruh terhadap prestasi kerja karyawanPT. JAPFA COMFEED INDONESIA Tbk, Devisi FARM 1 PADANG.

\section{METODE PENELITIAN}

Penelitian ini berdasarkan tujuan yang ingin dicapai melalui pendekatan deskriptif dan asosiasif yakni menggambarkan secara deskriptif mengenai Pengaruh dari berbagai variabel melalui pengujian hipotesis. Mengingat jenis yang dipilih, maka metode penelitian yang digunakan adalah metode kuantitatif. Penelitian ini dilakukan dengan menyebarkan kuesioner dan responden yang mengisi kuesioner tersebut adalah karyawan dan HRD devisi Farm 1 pada PT Japfa Comfeed Indonesia Tbk cabang Padang. Data yang digunakan dalam penelitian ini meliputi:

1. Data Primer yang merupakan sumber data yang langsung memberikan data kepada pengumpul data.

2. Data Sekunder yang merupakan data penelitian yang diperoleh secara tidak langsungmelalui media .

Metode pengumpulan data yang digunakan dalam penelitian ini adalah: Kuesioner dan Studi Pustaka.

Teknik Analisis Data

$$
\text { Mengetahui pengaruh Gaya }
$$

Kepemimpinan dan Kompensasi terhadap Prestasi Kerja di PT. Japfa Comfeed Indonesia Tbk Padang maka dengan ini dilakukan pengujian data kusioner yang diajukan kepada 100 orang responden penelitian

\section{Uji Validitas}

Setelah dilakukan pengolahan data dengan menggunakan SPSS for windows maka diperoleh hasil uji validitas untuk menunjukkan kevalidan data yang diperoleh. Hasil uji validitas variabel penelitian adalah sebagai berikut:

\section{Gaya Kepemimpinan}

Dari data yang diperoleh berdasarkan jawaban responden maka dapat dilihat variabel Gaya Kepemimpinan nilai validitasnya seperti :

Hasil Uji Validitas Variabel Gaya Kepemimpinan

\section{Item-Total Statistics}

\begin{tabular}{|l|l|l|l|l|}
\hline & $\begin{array}{l}\text { Scale } \\
\text { Mean if } \\
\text { Item } \\
\text { Deleted }\end{array}$ & $\begin{array}{l}\text { Scale } \\
\text { Variance } \\
\text { if Item }\end{array}$ & $\begin{array}{l}\text { Corrected } \\
\text { Deleted }\end{array}$ & $\begin{array}{l}\text { Cronbach's } \\
\text { Item-Total } \\
\text { Correlation }\end{array}$ \\
$\begin{array}{l}\text { Altem if } \\
\text { Deleted }\end{array}$ \\
\hline X1.1 & 15.8200 & 4.311 & .565 & .624 \\
$\mathrm{X} 1.2$ & 15.8200 & 4.594 & .551 & .633 \\
$\mathrm{X} 1.3$ & 15.4700 & 5.100 & .412 & .689 \\
$\mathrm{X} 1.4$ & 15.6400 & 4.778 & .508 & .651 \\
$\mathrm{X} 1.5$ & 15.6100 & 5.331 & .327 & .720 \\
\hline
\end{tabular}

Sumber : Data Kuesioner yang diolah, 2018

Dapat disimpulkan bahwa dari 5
item pernyataan variabel Gaya Kepemimpinan dikatakan valid adalah sebanyak 5 itemkarena Corrected ItemTotal Correlation dari pernyataan tersebut lebih besar dari 0,300 sehingga dapat digunakan untuk penelitian lebih lanjut.

\section{Kompensasi}

Dari data yang diperoleh berdasarkan jawaban responden maka dapat dilihat variabel Kompensasi nilai validitasnya seperti yang terdapat pada tabel berikut: 
Hasil Uji Validitas Variabel Kompensasi

Item-Total Statistics

\begin{tabular}{|c|c|c|c|c|}
\hline & \begin{tabular}{|l|} 
Scale \\
Mean if \\
Item \\
Deleted \\
\end{tabular} & \begin{tabular}{|l} 
Scale \\
Varianc \\
e if Item \\
Deleted
\end{tabular} & $\begin{array}{l}\text { Corrected } \\
\text { Item-Total } \\
\text { Correlatio } \\
n\end{array}$ & $\begin{array}{l}\text { Cronbach' } \\
\text { s Alpha if } \\
\text { Item } \\
\text { Deleted }\end{array}$ \\
\hline $\begin{array}{l}\mathrm{X} 2 . \\
1\end{array}$ & $\begin{array}{l}15.970 \\
0\end{array}$ & 3.504 & .441 & .546 \\
\hline $\begin{array}{l}X 2 . \\
2\end{array}$ & $\begin{array}{l}16.110 \\
0\end{array}$ & 3.513 & .416 & .556 \\
\hline $\begin{array}{l}X 2 . \\
3\end{array}$ & $\begin{array}{l}16.330 \\
0\end{array}$ & 3.597 & .300 & .614 \\
\hline $\begin{array}{l}X 2 . \\
4\end{array}$ & $\begin{array}{l}16.340 \\
0\end{array}$ & 3.257 & .394 & .567 \\
\hline $\begin{array}{l}X 2 . \\
5\end{array}$ & $\begin{array}{l}16.010 \\
0\end{array}$ & 3.566 & .364 & .580 \\
\hline
\end{tabular}

Sumber : Data Kuesioner yang

diolah, 2018

Dapat disimpulkan bahwa dari 5 butir pernyataan variabel Kompensasi dikatakan valid karena nilai Corrected Item-Total Correlation melebihi 0,300 sehingga dapat digunakan untuk penelitian lebih lanjut.

\section{Prestasi Kerja}

Dari data yang diperoleh berdasarkan jawaban responden maka dapat dilihat variabel Prestasi Kerja nilai validitasnya seperti yberikut:

\section{Hasil Uji Validitas Variabel Prestasi Kerja}

Item-Total Statistics

\begin{tabular}{|l|l|l|l|l|}
\hline & $\begin{array}{l}\text { Scale } \\
\text { Mean if } \\
\text { Item } \\
\text { Deleted }\end{array}$ & $\begin{array}{l}\text { Scale } \\
\text { Variance } \\
\text { if Item } \\
\text { Deleted }\end{array}$ & $\begin{array}{l}\text { Corrected } \\
\text { Item-Total } \\
\text { Correlation }\end{array}$ & $\begin{array}{l}\text { Cronbach's } \\
\text { Alpha if } \\
\text { Item } \\
\text { Deleted }\end{array}$ \\
\hline Y1 & 16.2800 & 4.709 & .612 & .791 \\
Y2 & 16.1700 & 4.668 & .615 & .790 \\
Y3 & 16.1600 & 4.439 & .719 & .759 \\
Y4 & 16.2200 & 4.779 & .640 & .784 \\
Y5 & 16.0100 & 4.980 & .512 & .819 \\
\hline \multicolumn{5}{|c|}{ Sumber : Data Kuesioner yang }
\end{tabular}
diolah, 2018

Dapat disimpulkan bahwa dari 5 butir pernyataan variabel Prestasi Kerja dikatakan valid adalah sebanyak 5 item karena nilai Corrected Item-Total
Correlation melebihi 0,300 dan dapat digunakan untuk penelitian lebih lanjut.

\section{Uji Reliabilitas}

Setelah melakukan uji validitas kemudian dilanjutkan dengan uji reliabilitas. Hasil olahan data tersebut dikemukakan pada tabel berikut:

\section{Hasil Uji Reliabilitas}

\begin{tabular}{|l|l|l|l|}
\hline $\begin{array}{l}\mathbf{N} \\
\mathbf{0}\end{array}$ & Variabel & $\begin{array}{l}\text { Cronb } \\
\text { ach's } \\
\text { Alpha }\end{array}$ & $\begin{array}{l}\text { Ketera } \\
\text { ngan }\end{array}$ \\
\hline $\mathbf{1}$ & $\begin{array}{l}\text { Gaya } \\
\text { Kepemi } \\
\text { mpinan }\end{array}$ & 0,714 & $\begin{array}{l}\text { Reliabe } \\
1\end{array}$ \\
\hline $\mathbf{2}$ & $\begin{array}{l}\text { Kompen } \\
\text { sasi }\end{array}$ & 0,627 & $\begin{array}{l}\text { Reliabe } \\
1\end{array}$ \\
\hline $\mathbf{3}$ & $\begin{array}{l}\text { Prestasi } \\
\text { Kerja }\end{array}$ & 0,824 & $\begin{array}{l}\text { Reliabe } \\
1\end{array}$ \\
\hline
\end{tabular}

Sumber : Data Kuesioner yang diolah, 2017

Dapat disimpulkan bahwa dari uji reliabilitas dihasilkan nilai Cronbach's Alpha untuk variabel penelitian Gaya Kepemimpinan, Kompensasi dan Prestasi Kerja lebih besar dari 0,60 yang memberikan hasil bahwa variabel yang diteliti memenuhi syarat untuk konsistensi. Jadi item-item pertanyaan untuk variabel tersebut dapat dipakai sebagai alat ukur dalam penelitian.

\section{Hasil Uji Asumsi Klasik}

\section{Uji Normalitas}

Uji normalitas bertujuan untuk menguji apakah dalam model regresi variabel pengganggu atau residual memiliki distribusi normal. Pengujian normalitas dapat dilakukan dengan menggunakan Kolmogorov smirnov (Ks) dan melihat Scatterplot titik penyebaran indikator variabel independen terhadap variabel dependen, dengan melihat perbandingan nilai signifikasi yang dihasilkan > 0.05 maka distribusi datanya dikatakan normal sedangkan untuk scatterplot penyebaran indikator hendaknya mendekati garis potong. Sebaliknya jika signifikasi yang dihasilkan $<0.05$ maka data tidal terdistribusi secara 
normal. Hasil uji normalitas data terdapat pada tabel bawah ini:

Hasil Uji Normalitas

One-Sample Kolmogorov-Smirnov Test

\begin{tabular}{|c|c|c|}
\hline & & $\begin{array}{l}\text { Unstandardized } \\
\text { Residual }\end{array}$ \\
\hline \multicolumn{2}{|l|}{$\mathrm{N}$} & 100 \\
\hline \multirow{2}{*}{$\begin{array}{l}\text { Normal } \\
\text { Parameters }\end{array}$} & Mean & .0000000 \\
\hline & $\begin{array}{l}\text { Std. } \\
\text { Deviation }\end{array}$ & 2.10868331 \\
\hline \multicolumn{2}{|c|}{ Most Extreme Absolute } & .082 \\
\hline \multirow[t]{2}{*}{ Differences } & Positive & .082 \\
\hline & Negative & -.067 \\
\hline \multirow{2}{*}{\multicolumn{2}{|c|}{$\begin{array}{l}\text { Kolmogorov-Smirnov Z } \\
\text { Asymp. Sig. (2-tailed) }\end{array}$}} & .820 \\
\hline & & .513 \\
\hline \multicolumn{2}{|c|}{ a. Test distribution is Normal. } & \\
\hline
\end{tabular}

Sumber: Data Kuesioner yang diolah, 2018

Dapat dilihat bahwa hasil uji normalitas menunjukkan bahwa nilai signifikansi pengujian KolmogorovSmirnov sebsesar $0,849>$ dari 0,05 berdistribusi normal maka data tersebut dapat digunakan untuk penelitian lebih lanjut.

\section{Hasil Uji Multikolinearitas}

Uji multikorelasi bertujuan untuk melihat korelasi antar variabel indenpenden (X). Apabila terdapat autokorelasi yang signifikan antar sesama variabel indenpenden maka harus dieliminasi dari analisis regresi berganda. Uji multikoloniearitas dapat diuji dengan nilai VIF untuk masing-masing variabel indenpenden. Persyaratan untuk bebas dari multikoloniearitas adalah apabila angka tolerance diatas 0,10 dan VIF $<10$ maka dikatakan tidak terdapat gejala multikoloniearitas. Hasil ini sesuai dengan pengujian multikoloniearitas yang terdapat pada tabel berikut :

Hasil Uji Multikolinearitas

\begin{tabular}{|c|c|c|c|c|c|}
\hline Model & $\begin{array}{l}\text { Unstandar } \\
\text { dized } \\
\text { Coefficien } \\
\text { ts }\end{array}$ & $\begin{array}{l}\text { Standar } \\
\text { dized } \\
\text { Coeffici } \\
\text { ents }\end{array}$ & $\mathrm{T}$ & q. & $\begin{array}{l}\text { Collinear } \\
\text { y Statistic }\end{array}$ \\
\hline
\end{tabular}

\begin{tabular}{|l|l|l|l|l|l|l|l|}
\hline & B & $\begin{array}{l}\text { Std. } \\
\text { Error }\end{array}$ & Beta & & $\begin{array}{l}\text { Tolera } \\
\text { nce }\end{array}$ & VIF \\
\hline 1 (Constant & 4.7 & 2.066 & & 2.2 & .0 & & \\
) & 05 & & & 78 & 25 & & \\
Gaya & .24 & .094 & .245 & 2.6 & .0 & & 1.3 \\
Kepemim & 5 & .738 & 10 & & 54 \\
pinan & & & & & & & 1.3 \\
Kompens & .53 & .112 & .445 & 4.7 & .0 & .738 & 54 \\
asi & 0 & & & 48 & 00 & & 54 \\
\hline
\end{tabular}

Sumber: Data Kuesioner yang diolah, 2018

Dapat diketahui bahwa nilai tolerance masing-masing variabel independen bernilai sama yaitu 0,738 berada di atas standar tolerance 0,10 sedangkan nilai VIF semua variabel indenpendennya lebih kecil dari 10, yaitu 1,354 Hal ini berarti bahwa hasil analisis menunjukan tidak ada masalah multikoloniearitas sehingga pengujian layak menggunakan model regresi berganda.

\section{Hasil Uji Heteroskedastisitas}

Uji heteroskedastisitas digunakan untuk melihat apakah dalam sebuah model regresi terjadi ketidaksamaan varians dari residual atas suatu pengamatan ke pengamatan lain. Jika varians dari residual suatu pengamatan ke pengamatan lain tetap, maka disebut homokedastisitas dan jika berbeda disebut heterokedastisitas. Untuk mendeteksi adanya gejala heterokedastisitas dilakukan uji Glejser dengan melihat Scatterplot penyebaran titik yang tidak membentuk pola tertentu. Hasil pengujian dapat dilihat pada gambar berikut :

Hasil Uji Heteroskedastisitas

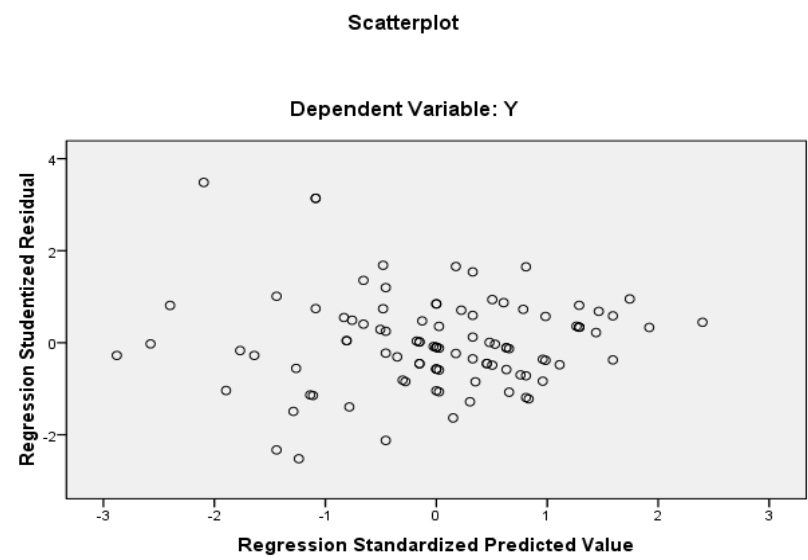


Dari gambar di atas dapat dilihat bahwa adanya penyebaran titik atau lingkaran Regresion Standarized Predicted Value yang tidak membentuk suatu pola tertentu seperti garis jadi dapat disimpulkan bahwa variabel yang diuji tidak memiliki gajala Heteroskedastisitas sehingga penelitian ini dapat dilanjutkan.

\section{Analisis Regresi Linier Berganda}

Untuk menguji hipotesis yang menyatakan bahwa ada pengaruh antara Gaya Kepemimpinan dan Kompensasi terhadap Prestasi Kerja di PT. Japfa Comfeed Indonesia Tbk Padang dengan penganalisaan data dengan menggunakan analisis regresi linier berganda denga menggunakan program SPSS for Windows seperti :

\section{Hasil Analisis Regresi Linier Berganda}

\begin{tabular}{|c|c|c|c|c|c|c|c|}
\hline \multirow[b]{2}{*}{ Model } & \multicolumn{2}{|c|}{$\begin{array}{l}\text { Unstandar } \\
\text { dized } \\
\text { Coefficien } \\
\text { ts }\end{array}$} & \multirow{2}{*}{\begin{tabular}{|l|}
$\begin{array}{l}\text { Standar } \\
\text { dized } \\
\text { Coeffici } \\
\text { ents }\end{array}$ \\
Beta \\
\end{tabular}} & \multirow[b]{2}{*}{$\mathrm{T}$} & \multirow[b]{2}{*}{$\begin{array}{l}\text { Si } \\
g .\end{array}$} & \multicolumn{2}{|c|}{$\begin{array}{l}\text { Collinearit } \\
\text { y Statistics }\end{array}$} \\
\hline & B & \begin{tabular}{|l|} 
Std. \\
Error
\end{tabular} & & & & $\begin{array}{l}\text { Tolera } \\
\text { nce }\end{array}$ & VIF \\
\hline 1 (Constant & $\begin{array}{l}4.7 \\
05\end{array}$ & 2.066 & & $\begin{array}{l}2.2 \\
78\end{array}$ & \begin{tabular}{|l}
.0 \\
25
\end{tabular} & & \\
\hline $\begin{array}{l}\text { Gaya } \\
\text { Kepemim } \\
\text { pinan }\end{array}$ & $\begin{array}{l}.24 \\
5\end{array}$ & .094 & .245 & $\begin{array}{l}2.6 \\
10\end{array}$ & $\begin{array}{l}.0 \\
10\end{array}$ & .738 & $\begin{array}{l}1.3 \\
54\end{array}$ \\
\hline $\begin{array}{l}\text { Kompens } \\
\text { asi }\end{array}$ & $\begin{array}{l}.53 \\
0\end{array}$ & .112 & .445 & $\begin{array}{l}4.7 \\
48\end{array}$ & $\begin{array}{l}.0 \\
00\end{array}$ & .738 & $\begin{array}{l}1.3 \\
54\end{array}$ \\
\hline
\end{tabular}

Sumber: Data Kuesioner yang diolah, 2017

Berdasarkan tabel maka ringkasan hasil pengujian dapat diformulasikan persamaan regresinya sebagai berikut:

$$
\begin{aligned}
& Y=4,705+0,245 X_{1}+0,530 X_{2}+e \\
& \mathrm{Y}=\text { Prestasi Kerja } \\
& \mathrm{X} 1=\text { Gaya Kepemimpinan } \\
& \mathrm{X} 2=\text { Kompensasi } \\
& \mathrm{e} \quad=\text { error }
\end{aligned}
$$

Dari persamaan tersebut dapat ditarik kesimpulan bahwa, konstanta menunjukkan tanpa variabel bebas (Gaya Kepemimpinan dan Kompensasi) maka peningkatan prestasi kerja yaitu sebesar nilai konstanta yang dihasilkan yaitu 4,705. Namun jika ada variabel Gaya Kepemimpinan dan Kompensasi maka keputusan prestasi kerja akan meningkat karena variabel Gaya Kepemimpinan dan Kompensasi memberikan pengaruh positif terhadap prestasi kerja.

Variabel gaya kepemimpinan mempunyai nilai koefisien sebesar 0,254, artinya apabila gaya kepemimpinan naik sebesar 0,254 maka prestasi kerja akan meningkat sebesar 0,254 $(25,4 \%)$ dengan asusmsi variabel lain bernilai tetap atau nol.

Variabel kompensasi mempunyai nilai koefisien sebesar 0,530, artinya apabila kompensasi naik sebesar 0,530 maka prestasi kerja juga ikut meningkat sebesar $0,530 \quad(53,0 \%)$ dengan asumsi variabel lainnya bernilai tetap atau nol.

\section{Uji Korelasi linear berganda dan Determinasi}

Analisa korelasi linier berganda dan determinasi berganda dapat dilakukan dengan menggunakan program SPSS for Windows seperti yang dikemukakan pada tabel :

Korelasi dan determinasi

\begin{tabular}{|l|l|l|l|l|}
\hline Model & $\mathrm{R}$ & $\begin{array}{l}\mathrm{R} \\
\text { Square }\end{array}$ & $\begin{array}{l}\text { Adjusted } \mathrm{R} \\
\text { Square }\end{array}$ & $\begin{array}{l}\text { Std. Error of } \\
\text { the Estimate }\end{array}$ \\
\hline 1 & $.608^{\mathrm{a}}$ & .370 & .357 & 2.13031 \\
\hline
\end{tabular}

Sumber: Data Kuesioner yang diolah, 2018

Berdasarkan tabel diatas maka ringkasan hasil korelasi dan determinasi adalah sebagai berikut:

1. $\mathrm{R}=0,608$ berarti nilai korelasi berada antara 0,41 sampai dengan 0,70 berarti korelasi dari variabel Gaya Kepemimpinan (X1), dan variabel Kompensasi (X2), terhadap Prestasi Kerja (Y) memiliki keeratan yang kuat.

2. Adjusted $R$ Square $=0,357$ berarti $35,7 \%$ dari variasi nilai variabel prestasi kerja dipengaruhi oleh variabel Gaya Kepemimpinan (X1), dan variabel Kompensasi (X2) sedangkan sisanya $64,3 \%$ dijelaskan 
oleh variabel-variabel lain yang tidak diteliti dalam penelitian ini.

\section{Uji Hipotesis}

\section{Uji Parsial (T-test)}

Pengujian ini bertujuan untuk mengetahui hubungan signifikan dari masing-masing variabel independen terhadap variabel dependen. Uji $t$ dilakukan untuk memeriksa lebih lanjut manakah diantara variabel independen tersebut signifikan atau tidak terhadap prestasi kerja yang dikemukakan pada tabel berikut :

\section{Hasil Uji t}

\begin{tabular}{|c|c|c|c|c|c|c|c|}
\hline \multirow[b]{2}{*}{ Model } & \multicolumn{2}{|c|}{$\begin{array}{l}\text { Unstandar } \\
\text { dized } \\
\text { Coefficien } \\
\text { ts }\end{array}$} & \multirow{2}{*}{$\begin{array}{l}\text { Standar } \\
\text { dized } \\
\text { Coeffici } \\
\text { ents } \\
\text { Beta }\end{array}$} & \multirow[b]{2}{*}{$\mathrm{T}$} & \multirow[b]{2}{*}{$\begin{array}{l}\mathrm{Si} \\
\mathrm{g} .\end{array}$} & \multicolumn{2}{|c|}{$\begin{array}{l}\text { Collinearit } \\
\text { y Statistics }\end{array}$} \\
\hline & B & $\begin{array}{l}\text { Std. } \\
\text { Error }\end{array}$ & & & & $\begin{array}{l}\text { Tolera } \\
\text { nce }\end{array}$ & VIF \\
\hline 1 (Constant & $\begin{array}{l}4.7 \\
05\end{array}$ & 2.066 & & $\begin{array}{l}2.2 \\
78\end{array}$ & $\begin{array}{l}.0 \\
25\end{array}$ & & \\
\hline $\begin{array}{l}\text { Gaya } \\
\text { Kepemim } \\
\text { pinan }\end{array}$ & $\begin{array}{l}.24 \\
5\end{array}$ & .094 & .245 & $\begin{array}{l}2.6 \\
10\end{array}$ & $\begin{array}{l}.0 \\
10\end{array}$ & .738 & $\begin{array}{l}1.3 \\
54\end{array}$ \\
\hline $\begin{array}{l}\text { Kompens } \\
\text { asi }\end{array}$ & $\begin{array}{l}.53 \\
0\end{array}$ & .112 & .445 & $\begin{array}{l}4.7 \\
48\end{array}$ & $\begin{array}{l}.0 \\
00\end{array}$ & .738 & $\begin{array}{l}1.3 \\
54\end{array}$ \\
\hline
\end{tabular}

Sumber: Data Kuesioner yang diolah, 2018

Dari tabel diatas diketahui diperoleh nilai t-hitung untuk variabel Gaya Kepemimpinan sebesar 2,610>t-tabel 1,66088 dan nilai signifikansi variabel Gaya Kepemimpinan (X1) sebesar 0,010 < $0,05=\mathrm{a}$ maka H1 diterima, berarti terdapat pengaruh positif dan signifikan antara variabel Gaya Kepemimpinan (X1) terhadap Prestasi Kerja (Y) di PT Japfa Comfeed Indonesia Tbk Padang.

Untuk variabel kompensasi terdapat nilai t-hitung sebesar $4,749>$ t-tabel 1,66088 dengan nilai signifikansi variabel kompensasi (X2) sebesar 0,00 < 0,05 maka H2 diterima, berarti terdapat pengaruh positif dan signifikan antara variabel kompensasi (X2) terhadap prestasi kerja (Y) di PT. Japfa Comfeed Indonesia Tbk.

\subsection{Uji F}

Pengujian ini bertujuan untuk menunjukkan apakah semua variabel independen dari peningkatan penjualan yang dimasukan dalam model mempunyai pengaruh secara bersama-sama berpengaruh terhadap variabel dependen.

\section{Hasil Uji F}

\begin{tabular}{|l|l|l|l|l|l|}
\hline Model & $\begin{array}{l}\text { Sum of } \\
\text { Squares }\end{array}$ & df & $\begin{array}{l}\text { Mean } \\
\text { Square }\end{array}$ & F & Sig. \\
\hline 1 Regression & 258.382 & 2 & 129.191 & 28.467 & $.000^{\text {a }}$ \\
Residual & 440.208 & 97 & 4.538 & & \\
Total & 698.590 & 99 & & & \\
\hline
\end{tabular}

Berdasarkan dari hasil pengujian pada tabel diatas dapat dilihat pada nilai $\mathrm{F}$ hitung sebesar 28,467 dan signifikansi 0,000 . Dengan menggunakan tingkat $\alpha$ (Alfa) $=0,05$ atau 5\% maka dan $\mathrm{Ha}$ diterima. Penolakan Ho dibuktikan dengan hasil perhitungan bahwa nilai Sig. $(0,000)$ $<0,05$ sehingga dapat disimpulkan bahwa tabel 4.18 diketahui variabel Gaya Kepemimpinan dan Kompensasi memiliki pengaruh yang signifikan terhadap Prestasi Kerja di PT. Japfa Comfeed Indonesia Tbk Padang.

\section{Kesimpulan}

Berdasarkan uraian dan hasil analisis pada bab-bab sebelumnya mengenai pengaruh bauran promosi terhadap peningkatan penjualan dapat diambil kesimpulan sebagai berikut:

1. Gaya Kepemimpinan berpengaruh signifikan terhadap prestasi kerja di PT. Japfa Comfeed Indonesia Tbk Padang karena angka signifikansi sebesar $0,010<0,05$, maka dapat diambil kesimpulan bahwa Gaya Kepemimpinan secara parsial berpengaruh signifikan terhadap prestasi kerja di Japfa Comfeed Indonesia Tbk Padang (H1 diterima).

2. Kompensasi berpengaruh signifikan terhadap prestasi kerja di PT. Japfa Comfeed Indonesia Tbk Padang karena angka signifikansi sebesar 0,000 lebih kecil dari level of 
3. signifikan 0,05 ( $\operatorname{Sig} 0,000<0,05$ ), maka dapat diambil kesimpulan bahwa kompensasi secara parsial berpengaruh signifikan terhadap prestasi kerja di PT. Japfa Comfeed Indonesia Tbk Padang (H2 diterima).

\section{Saran}

Berdasarkan kepada keterbatasan penelitian yang telah dilakukan maka diajukan beberapa saran yang dapat memberikan manfaat positif antara lain sebagai berikut:

1. Manager atau pimpinan PT. Japfa Comfeed Indonesia Tbk Padang sebaiknya melakukan evaluasi

\section{DAFTAR PUSTAKA}

Hasibuan, Malayu. 2000. Manajemen Sumber Daya Manusia. PT Bumi Aksara. Jakarta.

Ghazali, Imam, 2016, Aplikasi Analisis Multivariat Dengan Program IBM SPSS 23, Cetakan kedelapan, Universitas Diponegoro, Semarang.

Ghozali, Imam. 2005. Aplikasi Analisis Multivariate dengan Program SPSS. Semarang: BP Universitas Diponegoro. Semarang.

Hutapea, Thoha. 2008. Kompensasi Kerja.Jakarta : rajawali Pers.

Mangkunegara, Prabu, anwar.2005. Sumber Daya Manusia Perusahaan. Bandung. Remaja Pustaka Karya.

Marlius, D. (2017). Keputusan Pembelian Berdasarkan Faktor Psikologis Dan Bauran Pemasaran Pada PT. Intercom Mobilindo Padang. Jurnal Pundi. Volume 1. No. 1. Hal. 5766. https://doi.org/10.31575/jp.v1i1.9

Robbins, Stephen. P. 2006. Perilaku organisasi. Edisi Bahasa Indonesia. PT Indeks Kelompok GRAMEDIA. Jakarta. terhadap karyawan mengenai gaya kepemimpinan yang diterapkan sehingga dapat memberikan perubahan terhadap prestasi kerja karyawan.

2. Manager atau pimpinan PT Japfa Comfeed Indonesia Tbk Padang sebaiknya melakukan pendekatan terhadap karyawan dan memberikan arahan dengan terstruktur dan jelas agar karywan dapat bekerja secara produktif maka akan terwujud prestasi kerja bagi setiap karyawan.

Robbins, Stephen. P. dan Mary Coulter. 2005. Manajemen. PT INDEKS Kelompok. Gramedia. Jakarta.

Supranto, J. 2001. Statistik: Teori dan Aplikasi. Edisi keenam. Erlangga. Jakarta.

Tampubolon, Biatna. D.2007. Analisis Faktor Gaya Kepemimpinan.No 9 Hal : 106. 